Acta vet. scand. 1984, 25, 151-163.

From the National Veterinary Institute, Oslo, Norway, and the Department of Epidemiology and Preventive Medicine, University of California, Davis, USA.

\title{
A COMPARISON OF TWO DOSE LEVELS OF ANTIBIOTICS FOR INTRAMAMMARY TREATMENT OF CLINICAL MASTITIS IN COWS
}

\author{
By \\ J. Bjorland, G. Bakken, R. Eidsaa, T. B. Farver, L. Homme, \\ $N$. Leine and E. Onstad
}

BJORLAND, J., G. BAKKEN, R. EIDSAA, T. B. FARVER, L. HOMME, N. LEINE and E. ONSTAD: A comparison of two dose levels of antibiotics for intramammary treatment of clinical mastitis in cows. Acta vet. scand. 1984, 25, 151-163. - A clinical trial was conducted in Nordre Valdres, Norway, to examine the effect of a low-level vs. a high-level intramammary antibiotic treatment of clinical mastitis. It was also of interest to identify significant risk factors and to estimate the probability of no recovery for given defined levels of risk factors. Quarter milk samples from 166 cows with clinical mastitis were examined before and after treatment, at 3 weeks interval. The two treatment levels did not differ significantly with respect to recovery rate. The probability of no recovery could be estimated by using information on the severity of general clinical signs, lactation number, bacteriological findings, and quarter location.

bovine mastitis; therapy; bacteria; prognosis; clinicaltrial; logistic regression; risk factors.

Mastitis in dairy cows is a world-wide disease problem accounting for major economic losses (Dobbins 1977, Kingwill 1978). The prevalence of mastitis can be reduced by preventing the occurrence of new cases and by shortening the duration of an established inflammation. Favorable environment, including that induced by proper herd management, is important for disease prevention. To eliminate persistent infections, however, therapy or culling have to be applied (Plommet \& Le Loudec 1975, Kingwill 1978, Ziv 1980).

The efficacy of antimicrobial mastitis therapy depends on various factors such as the type of drug, the dose level, the route 
of administration, and the duration of the treatment. In regard to dose level, comparative studies indicate little relationship between in vitro sensitivity and in vivo response to an antibiotic. Therefore, the degree of association between dose of a drug and the desired therapeutic results should be determined by clinical experiments in the field ( $Z i v$ 1978).

The primary objective of this study was to examine the effect of a high-level vs. a low-level intramammary treatment of clinical mastitis in cows. Thus the main question of interest was whether the two treatment levels differ with respect to recovery rate. A secondary objective was to examine the epidemiologic relationships among important variables from the data recorded. Finally, after identifying certain variables as significant risk factors, it was desired to estimate the probability of no recovery for given defined levels of the risk factors.

\section{MATERIALS AND METHODS}

\section{Data collection}

The clinical trial was conducted in Nordre Valdres, Norway, from October 1981 until January 1983. Four different veterinarians were responsible for the clinical examination, the collection of milk samples, and the treatment of the cows; the milk samples were examined at the National Veterinary Institute of Norway. The two treatment alternatives to be compared were distinguished by different color of the injectors; thus the formulations were unknown for the involved veterinarians and dairymen as well as for the laboratory personnel and the veterinarian responsible for statistical analysis.

The unit of interest was the individual cow, and the inclusion criteria were as follows: milking cows with clinical mastitis in one or two quarters, within 6 months after previous delivery. Cows with clinical teat damage or chronic udder changes were excluded from the study. All cows were of the NRF breed (Norsk Rødt Fe, i.e. Norwegian Red Cattle). Cows with previous mastitis in the present lactation and cows with simultaneous clinical symptoms of other diseases were also excluded from the trial as were cows with antibiotic or chemotherapeutic residues in the milk.

After the clinical examination of the patient, the California Mastitis Test (CMT) was performed and quarter milk samples were collected after disinfecting the teat ends with a cotton swab 
soaked in $70 \%$ ethanol. The veterinarian chose the treatment alternative for the first case at the first farm randomly; treatment assignment then alernated between the two treatments for each new farm and for each new case at a certain farm. The treatment alternative for each case was coded on a health card system to insure the consistency of the treatment allocation procedure. The milk samples were mailed to the laboratory together with a form which was filled out by the veterinarian involved and which contained information such as cow identification number, lactation number, calving date, daily milk production, temperature and general condition, acute udder symptoms, CMT results, and intramammary treatment alternative. In the laboratory the CMT test was repeated, and the milk was examined bacteriologically, including tests for antibiotic sensitivity and tests for antimicrobial residues, using procedures described by Klastrup \& Schmidt Madsen (1974) with some slight modification (Bakken 1981). Each case was examined by the same veterinarian about 3 weeks $(22.96 \pm 5.6$ days $)$ after the initial examination and treatment, and quarter milk samples were obtained and tested using the same procedure.

A total number of 183 cows were initially selected. However, 17 of these cases were excluded from the study because of unforeseen circumstances such as broken test tubes during forwarding, insufficient milk quantity, detection of antibacterial residues in the milk, occurrence of new diseases or culling during the study period, or vague intial mastitis criteria after laboratory examinations.

\section{Definition of variables}

The variables used in the statistical analysis are listed in Table 1. The variable "Treatment" is based on an initial general and local treatment common for both treatment groups, followed by either a low-level or a high-level intramammary treatment given by the farmer on the first, second, and third evening after the initial treatment. The basic initial treatment was as follows: Intravenous injection of $1 \mathrm{ml}$ "Oxytocin vet." (L $\phi$ vens kemiske Fabrik) and subsequent milking of affected quarter(s); then application of "Streptocillin vet." (Novo Industrier A/S); $40 \mathrm{ml}$ intramuscular injection and $10 \mathrm{ml}$ intramammary infusion, followed by milking after $4 \mathrm{~h}$ and then every second hour until evening. "Streptocillin vet." has the following formulation: 
T a ble 1. Summary of categorization and coding and the number of cases in levels for factors examined in a clinical trial on mastitis treatment in Nordre Valdres, Norway, 1981-83.

\begin{tabular}{|c|c|c|c|c|c|}
\hline & Factor & Code & Category & Level & $\begin{array}{l}\text { Number } \\
\text { of cases }\end{array}$ \\
\hline 1. & Treatment & $\mathbf{T}$ & $\begin{array}{l}\text { Low-level } \\
\text { High-level }\end{array}$ & $\begin{array}{l}1 \\
2\end{array}$ & $\begin{array}{l}92 \\
74\end{array}$ \\
\hline 2. & Outcome & O & $\begin{array}{l}\text { Not recovered } \\
\text { Recovered }\end{array}$ & $\begin{array}{l}1 \\
2\end{array}$ & $\begin{array}{r}55 \\
111\end{array}$ \\
\hline 3. & Quarter location & $\mathrm{L}$ & $\begin{array}{l}\text { Front } \\
\text { Hind }\end{array}$ & $\begin{array}{l}1 \\
2\end{array}$ & $\begin{array}{l}37 \\
99\end{array}$ \\
\hline 4. & Lactation & $\mathbf{A}$ & $\begin{array}{l}\text { First } \\
\text { Second } \\
\text { Third } \\
\text { Fourth } \\
\text { Fifth or more }\end{array}$ & $\begin{array}{l}1 \\
2 \\
3 \\
4 \\
5\end{array}$ & $\begin{array}{l}64 \\
37 \\
34 \\
10 \\
21\end{array}$ \\
\hline 5. & Milk productiona & M & $\begin{array}{l}<11 \mathrm{~kg} \\
11-20 \mathrm{~kg} \\
21-30 \mathrm{~kg} \\
>30 \mathrm{~kg}\end{array}$ & $\begin{array}{l}1 \\
2 \\
3 \\
4\end{array}$ & $\begin{array}{r}18 \\
89 \\
46 \\
9\end{array}$ \\
\hline 6. & General conditionb & C & $\begin{array}{l}\text { No clinical signs } \\
\text { Moderate signs } \\
\text { Severe signs }\end{array}$ & $\begin{array}{l}1 \\
2 \\
3\end{array}$ & $\begin{array}{r}101 \\
39 \\
25\end{array}$ \\
\hline 7. & $\begin{array}{l}\text { Number of infected } \\
\text { quarters }\end{array}$ & $\mathbf{S}$ & $\begin{array}{l}\text { Single } \\
\text { Multiple }\end{array}$ & $\begin{array}{l}1 \\
2\end{array}$ & $\begin{array}{r}133 \\
33\end{array}$ \\
\hline 8. & Time since calving & $\mathbf{I}$ & $\begin{array}{l}<15 \text { days } \\
15-60 \text { days } \\
61-120 \text { days } \\
>120 \text { days }\end{array}$ & $\begin{array}{l}1 \\
2 \\
3 \\
4\end{array}$ & $\begin{array}{l}56 \\
50 \\
34 \\
26\end{array}$ \\
\hline 9. & $\begin{array}{l}\text { Time between } \\
\text { treatment and } \\
\text { control examination }\end{array}$ & $\mathbf{P}$ & $\begin{array}{l}<16 \text { days } \\
16-20 \text { days } \\
21-25 \text { days } \\
26-30 \text { days } \\
>30 \text { days }\end{array}$ & $\begin{array}{l}1 \\
2 \\
3 \\
4 \\
5\end{array}$ & $\begin{array}{r}8 \\
48 \\
70 \\
28 \\
12\end{array}$ \\
\hline 10. & Bacteriac & B & $\begin{array}{l}\text { S. aureus } \\
\text { Others }\end{array}$ & $\begin{array}{l}1 \\
2\end{array}$ & $\begin{array}{l}79 \\
55\end{array}$ \\
\hline
\end{tabular}

a 4 cases had incomplete data (lacking information)

b 1 case had incomplete data (lacking information)

c 32 cases had incomplete data because of negative bacteriological findings

Benzylpenicillinprocain $200000 \mathrm{IU}$, dihydrostreptomycin $250 \mathrm{mg}$. One low-level injector contains benzylpenicillinprocain 200000 IU, dihydrostreptomycin $200 \mathrm{mg}$. One high-level injector contains benzylpenicillinprocain $500000 \mathrm{IU}$, dihydrostreptomycin $1000 \mathrm{mg}$. 
The variable "Outcome" with the two levels "Not recovered" and "Recovered" is based on the laboratory diagnosis after the examination of the control milk samples. Four different diagnoses were used at the first and second laboratory examination: "Nonspecific mastitis", "Infectious mastitis", "Occurrence of microorganisms", and "Normal findings", coded from 1 to 4, respectively. Diagnoses 1 and 2 correspond to an outcome of "Not recovered", diagnoses 3 and 4 correspond to an outcome of "Recovered".

The other variables in the study are based on the following principles: The variable "Number of infected quarters" with the levels "Single" and "Multiple" identifies the number of quarters on each cow treated for clinical mastitis simultaneously. Since there could be several diagnoses among the quarters of an udder, a single diagnosis on a cow basis had to be determined. Thus the most seriously affected quarter was selected based on acute symptoms and CMT test results. Acute symptoms were recorded on an ordinal scale from 1 (normal) to 4. The variable "Bacteria" reflects whether the bacteriological examination resulted in detection of $S$. aureus or not, given positive bacteriological findings. Specification of bacteriological findings for all included cases before treatment is presented in Table 2. The variable "Milk pro-

T a b l e 2. Results of bacteriological examination before treatment from clinical trial on mastitis treatment in Nordre Valdres, Norway, $1981-83$.

\begin{tabular}{lcc}
\hline Bacteria isolated & Number of cases & Percentage \\
\hline S. aureus & 79 & 47.6 \\
S. epidermidis & 17 & 10.2 \\
E. coli & 13 & 7.8 \\
Str. dysgalactiae & 9 & 5.4 \\
๙-streptococcus & 8 & 4.8 \\
Str. uberis & 2 & 1.2 \\
Cor. pyogenes & 2 & 1.2 \\
Str. agalactiae & 1 & 0.5 \\
Bacillus & 1 & 0.6 \\
Klebsiella & 1 & 0.6 \\
Mixed flora & 1 & 0.6 \\
Negative findings & 32 & 19.3 \\
\hline \multicolumn{1}{c}{ Total } & 166 & 100.0 \\
\hline
\end{tabular}


duction" reflects the milk production on the last routine control day before mastitis occurred $(19.85 \pm 6.31 \mathrm{l})$. "General condition" is a variable resulting from the veterinarian's evaluation of general signs of disease like fever, anorexia, tachycardia etc. Level 1 indicates normality, level 2 and 3 reflect moderate and severe signs, respectively. The remaining variables listed in Table 1 such as "Quarter location", "Lactation", "Time since calving", and "Time between treatment and control examination" are selfexplanatory.

\section{Statistical analysis}

Since it was of primary interest to test for association between "Treatment" and the response variable "Outcome", it was necessary to control for possible confounding effects of other variables. BMDP4F computer program (Dixon 1981) was initially used to examine the relationship between "Treatment" and "Outcome" in the presence of other variables. This program fits loglinear models belonging to a hierarchial set in which higherorder interaction terms may be included in a model only after inclusion of related lower-order terms (Feinberg 1980). The first set of runs involved fitting all possible log-linear models including "Treatment", "Outcome" and a third variable which for each run was a different potentially confounding factor in the data set. The intention of these runs was to see if any of the least complex, good-fitting models included the interaction "Treatment" by "Outcome". It was also of interest to check for possible association between "Outcome" and other variables.

In order to fit a log-linear model which best explains the data, it was desirable to look at as many variables as possible in any run. Since the sample size of the data set was relatively small, only 4 variables at a time could be included in each possible model; this was necessary in order to avoid empty cells in the multi-dimensional frequency tables. Two of these variables in the four-factor models were "Outcome" and "Treatment". Using information from the previous runs involving 3 variables, variables which appeared to be associated with "Outcome" were selected as the other two variables in a given run involving 4 variables. Since BMDP4F does not automatically print out all possible models involving 4 variables, the relative importance of each selected effect had to be screened using tests of marginal 
and partial association (Brown 1976). On the basis of information from the screening tests, log-linear models including necessary and questionable effects were specified and fit.

The stepwise logistic regression procedure was applied in order to estimate the probability of no recovery for given levels of the risk factors. BMDPLR computer program was used with all the variables listed in Table 1 and the interaction involving "Bacteria" and "General condition" available for entry; all variables were categorical in nature. Because 32 cases had no information on type of bacteria detected, the sample size was reduced when "Bacteria" was available for entry. Therefore, a second run was made in which this variable was not available for entry; the results from this run were thus based on the total sample size. These two runs were repeated using the variables "Milk production", "Time since calving" and "Time between treatment and control examination" in their original interval form.

\section{RESULTS}

The good-fitting log-linear models including the variables "Treatment" and "Outcome" in the presence of a third variable are as follows (given the codes from Table 1 in "bracket" notation ): $[\mathrm{OL}][\mathbf{T L}],[\mathrm{OC}][\mathrm{T}],[\mathrm{OB}][\mathbf{T}],[\mathrm{O}][\mathbf{T}][\mathbf{I}],[\mathrm{O}][\mathbf{T}][\mathbf{M}]$, $[\mathrm{O}][\mathbf{T}][\mathrm{A}],[\mathrm{O}][\mathbf{T}][\mathrm{S}],[\mathrm{O}][\mathrm{T}][\mathrm{P}]$. No factor $\mathrm{O}$ by $\mathrm{T}$ interaction term appears in any of the models. The factors $\mathrm{L}, \mathrm{C}$, and $\mathrm{B}$, however, are associated with factor $O$.

The factors $\mathrm{L}, \mathrm{C}$, and $\mathrm{B}$ were used as the third and fourth variables, besides "Treatment" and "Outcome", to define 3 basic runs in which log-linear models involving 4 variables were fit. The tests for partial and marginal association and the subsequent goodness-of-fit tests resulted in the identification of the following good-fitting models: $[\mathrm{OC}][\mathrm{TL}],[\mathrm{OB}][\mathrm{TL}],[\mathrm{OBC}][\mathrm{T}]$. The model $[\mathrm{OBC}][\mathbf{T}]$ is questionable since several empty cells appeared in the multi-dimensional frequency table.

The BMDPLR program identified the factors which are important in order to predict the probability of no recovery. The stepwise logistic regression procedure using all factors available for entry, including the interaction term $B$ by $C\left(B^{\star} C\right)$, resulted in a model containing the terms B, C, and A. After excluding the variable "Bacteria" from the analysis, the program computed a gcod-fitting model which included the factors $\mathrm{C}, \mathrm{A}$, and $\mathrm{L}$. 
The results can be summarized as follows:

1 The variables "Treatment" and "Outcome" are not associated in any of the models, which indicates no significant difference between the two treaiment alternatives with respect to recovery rate.

2 When information on bacteriological examination is ignored, the probability of no recovery can be estimated by using information on general condition, lactation number, and quarter location.

3 When information about bacteriological examination is accounted for, the probability of no recovery depends on general condition, number of lactation, and type of bacteria detected, given positive bacteriological findings.

BMDPLR computer program provided predicted probabilities of no recovery for different combinations of risk factor levels. These results are presented in Table 3 and 4 corresponding to the two good-fitting logistic regression models. The total number of possible combinations of factor levels is 30 for each of the two good-fitting logistic regression models. However, because the computer program gives estimated probabilities only for factor level combinations (cells) which contain at least one case each in the data set, probabilities were not printed for 3 and 4 cells, respectively, in the two probability tables.

Table 3 shows that cows in 1 st lactation with mastitis on a front quarter and without general clinical signs have the lowest probability $(\mathrm{P}=\mathbf{0 . 0 9 1 0})$ of no recovery, and thus have the highest probability of recovery, within 3 weeks after treatment. Cows with mastitis on a hind quarter in the 3rd lactation with severe general signs have the highest probability of no recovery $(\mathrm{P}=\mathbf{0 . 8 0 8 2}$ ). Table 4 gives the highest probability of no recovery for cows with mastitis caused by $S$. aureus, in the 3rd lactation and with severe general signs $(\mathrm{P}=0.9563)$. The lowest probability of no recovery is for cows with mastitis caused by bacterias other than $S$. aureus in 1st lactation and with normal general condition $(\mathrm{P}=\mathbf{0 . 0 3 0 3})$. The probability of no recovery increases with increasing lactation number until lactation 3 ; thereafter the probability decreases. As an example, cows with mastitis caused by bacteria other than $S$. aureus and without general signs have the following probabilities of no recovery (given in order corresponding to lactation levels 1 to 5 ): 0.0303 , $0.0769,0.1425,0.1356,0.0983$. 
T a b l e 3. Predicted probabilities of no recovery for given levels of the risk factors "Lactation", "General condition", and "Quarter location"; from clinical trial on mastitis treatment in Nordre Valdres, Norway, $1981-83$.

\begin{tabular}{cccccccc}
\hline $\begin{array}{c}\text { Number } \\
\text { not } \\
\text { recovered }\end{array}$ & $\begin{array}{c}\text { Number } \\
\text { recovered }\end{array}$ & $\begin{array}{c}\text { Observed } \\
\text { proportion } \\
\text { not } \\
\text { recovered }\end{array}$ & $\begin{array}{c}\text { Predicted } \\
\text { probability } \\
\text { of no } \\
\text { recovery }\end{array}$ & $\begin{array}{c}\text { Standard } \\
\text { deviation } \\
\text { of } \\
\text { probabiltity }\end{array}$ & $\begin{array}{c}\text { Quarter } \\
\text { procation }\end{array}$ & Lactation & $\begin{array}{c}\text { General } \\
\text { condition }\end{array}$ \\
\hline 0 & 13 & 0.0000 & 0.0910 & 0.0381 & 1 & 1 & 1 \\
0 & 2 & 0.0000 & 0.4132 & 0.1298 & 1 & 3 & 2 \\
0 & 1 & 0.0000 & 0.2381 & 0.1355 & 1 & 4 & 1 \\
0 & 1 & 0.0000 & 0.3539 & 0.1768 & 1 & 4 & 2 \\
0 & 6 & 0.0000 & 0.2006 & 0.0950 & 1 & 5 & 1 \\
0 & 3 & 0.0000 & 0.4571 & 0.1515 & 2 & 5 & 2 \\
1 & 6 & 0.1429 & 0.1493 & 0.0695 & 1 & 1 & 2 \\
4 & 22 & 0.1538 & 0.1609 & 0.0544 & 2 & 1 & 1 \\
1 & 4 & 0.2000 & 0.3744 & 0.1602 & 2 & 4 & 1 \\
1 & 3 & 0.2500 & 0.3238 & 0.1143 & 1 & 2 & 2 \\
3 & 7 & 0.3000 & 0.3435 & 0.0972 & 2 & 2 & 1 \\
4 & 8 & 0.3333 & 0.2146 & 0.0770 & 1 & 2 & 1 \\
1 & 2 & 0.3333 & 0.7414 & 0.1155 & 2 & 2 & 3 \\
2 & 3 & 0.4000 & 0.2515 & 0.0919 & 2 & 1 & 2 \\
2 & 3 & 0.4000 & 0.5122 & 0.1291 & 2 & 1 & 3 \\
4 & 5 & 0.4444 & 0.2866 & 0.0923 & 1 & 3 & 1 \\
5 & 6 & 0.4545 & 0.4348 & 0.1035 & 2 & 3 & 1 \\
2 & 2 & 0.5000 & 0.6876 & 0.1242 & 1 & 3 & 3 \\
3 & 3 & 0.5000 & 0.4784 & 0.1215 & 2 & 2 & 2 \\
1 & 1 & 0.5000 & 0.8082 & 0.0903 & 2 & 3 & 3 \\
3 & 3 & 0.5000 & 0.3246 & 0.1171 & 2 & 5 & 1 \\
3 & 2 & 0.6000 & 0.3542 & 0.1221 & 1 & 1 & 3 \\
4 & 2 & 0.6667 & 0.5741 & 0.1217 & 2 & 3 & 2 \\
1 & 0 & 1.0000 & 0.5995 & 0.1430 & 1 & 2 & 3 \\
1 & 0 & 1.0000 & 0.5789 & 0.1603 & 1 & 5 & 3 \\
3 & 0 & 1.0000 & 0.5119 & 0.1759 & 2 & 4 & 2 \\
4 & 0 & 1.0000 & 0.7247 & 0.1260 & 2 & 5 & 3 \\
\hline
\end{tabular}

DISCUSSION

Only a small number of field studies with the purpose to establish optimal dose levels of antibiotic are found in the literature. One clinical trial was conducted to compare three levels of novobiocin, where infections by S. aureus were induced (Newbould 1979). Another study compared four formulations of antibiotics (Kapur \& Singh 1978). However, if a study is of multifactorial nature, it is usually necessary to adjust for confounding bias at the analytical phase, which requires appropriate computer 
T a b l e 4. Predicted probabilities of no recovery for given levels of the risk factors "Bacteria", "General condition", and "Lactation"; from clinical trial on mastitis treatment in Nordre Valdres, Norway, $1981-83$.

\begin{tabular}{cccccccc}
\hline $\begin{array}{c}\text { Number } \\
\text { not } \\
\text { recovered }\end{array}$ & $\begin{array}{c}\text { Number } \\
\text { recovered }\end{array}$ & $\begin{array}{c}\text { Observed } \\
\text { proportion } \\
\text { not } \\
\text { recovered }\end{array}$ & $\begin{array}{c}\text { Predicted } \\
\text { probability } \\
\text { of no } \\
\text { recovery }\end{array}$ & $\begin{array}{c}\text { Standard } \\
\text { deviation } \\
\text { of predicted } \\
\text { probability }\end{array}$ & Bacteria & $\begin{array}{c}\text { General } \\
\text { condition }\end{array}$ & Lactation \\
\hline 0 & 3 & 0.0000 & 0.1553 & 0.1258 & 2 & 1 & 4 \\
0 & 3 & 0.0000 & 0.0515 & 0.0341 & 2 & 2 & 1 \\
0 & 4 & 0.0000 & 0.1446 & 0.0838 & 2 & 2 & 2 \\
0 & 3 & 0.0000 & 0.2560 & 0.1274 & 2 & 2 & 3 \\
0 & 3 & 0.0000 & 0.1862 & 0.1275 & 2 & 2 & 5 \\
0 & 1 & 0.0000 & 0.7076 & 0.1539 & 2 & 3 & 3 \\
1 & 12 & 0.0769 & 0.0291 & 0.0188 & 2 & 1 & 1 \\
3 & 15 & 0.1667 & 0.2190 & 0.0767 & 1 & 1 & 1 \\
1 & 5 & 0.1667 & 0.0854 & 0.0478 & 2 & 1 & 2 \\
1 & 4 & 0.2000 & 0.1598 & 0.0850 & 2 & 1 & 3 \\
1 & 3 & 0.2500 & 0.1123 & 0.0793 & 2 & 1 & 5 \\
1 & 2 & 0.3333 & 0.5416 & 0.1868 & 1 & 1 & 5 \\
2 & 4 & 0.3333 & 0.3366 & 0.1271 & 1 & 2 & 1 \\
1 & 2 & 0.3333 & 0.5431 & 0.1713 & 2 & 3 & 2 \\
6 & 8 & 0.4286 & 0.4661 & 0.1113 & 1 & 1 & 2 \\
1 & 1 & 0.5000 & 0.6321 & 0.2034 & 1 & 1 & 4 \\
2 & 2 & 0.5000 & 0.7810 & 0.1153 & 1 & 3 & 1 \\
3 & 2 & 0.6000 & 0.2763 & 0.1285 & 2 & 3 & 1 \\
8 & 3 & 0.7273 & 0.6399 & 0.1131 & 1 & 1 & 3 \\
4 & 1 & 0.8000 & 0.7628 & 0.1095 & 1 & 2 & 3 \\
3 & 0 & 1.0000 & 0.6123 & 0.1430 & 1 & 2 & 2 \\
3 & 0 & 1.0000 & 0.7566 & 0.1695 & 1 & 2 & 4 \\
1 & 0 & 1.0000 & 0.9174 & 0.0579 & 1 & 3 & 2 \\
3 & 0 & 1.0000 & 0.9576 & 0.0334 & 1 & 3 & 3 \\
4 & 0 & 1.0000 & 0.9376 & 0.0564 & 1 & 3 & 5 \\
1 & 0 & 1.0000 & 0.6167 & 0.1997 & 2 & 3 & 5 \\
\hline & & & & & & & \\
\hline
\end{tabular}

programs available. This may be one of the reasons that recommended dose levels of intramammary antibiotics are seldom determined by experiments in the field (Plommet \& Le Louedec 1975, Mercer et al. 1976).

Mastitis is considered to be a multifactorial disease, where three biosystems participate in the developement of the disease: the host, infectious agents, and the environment (Tolle 1975). Not only the risk of infection, but probably also the likelihood of recovering depends on the effect of these main factors and the interactions among them. The data collected in this multifactorial study originated from all 3 biosystems, and statistical models 
were fit which described the data and clarified the relationships among the underlying variables. Although the analyses to a certain extent were limited because of a relatively small sample size, an association between "Treatment" and the response variable „Outcome" was not even close to significance at the 5 percent level. The improvement Chi-square value obtained by including the interaction term $\mathrm{O}^{*} \mathrm{~T}$ in the basic models with 3 main effects ranged from 0.68 to 1.55 ( 1 degree of freedom), which indicates a minimum P-value of 0.22 (non-significant). Further evidence of independence between the two factors "Treatment" and "Outcome" emerged when the variable "Treatment" failed to enter in any of the logistic regression models.

"Bacteria" is a variable which appeared to be strongly associated with "Outcome"; S. aureus was found to be a major udder pathogen associated with a low recovery rate. This is in agreement with other reports (Plommet \& Le Louedec 1975, Newbould 1979, Bakken 1981).

The nature of the association between "Outcome" and "General condition" indicates: the greater the severity of the infection, the lower the recovery rate observed. This relationship has previously been found in another study on mastitis in Norway (Bakken \& Gudding 1982).

The nature of the association between "Not recovered" and “Lactation" is positive for lactation levels 1,2 , and 3, but is negative for levels 4 and 5. A similar association has been reported earlier (Bakken 1981). This may reflect a culling practice by which cows with mastitis problems are slaughtered earlier than healthy cows.

A check was made as to whether the two treatment groups were comparable with respect to penicillin sensitivity. The number of cases with $\mathrm{S}$. aureus within each of the two groups was 41 and 38 , respectively; the corresponding number of penicillin resistant $S$. aureus cases was 2 and 5 . The total number of penicillin resistant bacterial strains was 12 for each of the 2 treatment groups. Based on these baseline comparisons, antibiotic sensitivity is not considered to be a source of bias in this study.

The stepwise logistic regression procedure permits reexamination, at every step, of the variables incorporated in the model in previous steps. A variable that entered at an early stage may, at a later stage, become superfluous because of its relationship with other variables now in the model. The interaction term $B^{\star} C$ entered the logistic model with a P-value for entry of 0.0572 after 
the main effects B, C, and A already had entered, but was promptly removed at the next step. None of the other variables available for entry had P-values close to the entry limit.

When all main factors were available for the logistic regression program except "Bacteria", factor "Quarter location" was included in the good-fitting model. When "Bacteria" was available, "Quarter location" did not enter. Its failure to enter may be explained in part by the loss of information with the exclusion of the 32 cases in which no bacteria were detected. Although factor $L$ was the last factor which entered significantly in the logistic regression model, this result indicates there is a higher probalility of no recovery among cows with infected hind quarters compared with those with infected front quarters. Other researchers have reported a higher frequency of $S$. aureus in hind quarters than in front quarters (Bakken 1981). This study failed to demonstrate an association betweeen "Bacteria" and "Quarter location".

The three remaining variables "Number of infected quarters", "Time since calving", and "Time between treatment and control examination" did not appear to effect the final results in this study. However, in regard to the time period between treatment and control examination, a shorter period may have given different results with respect to recovery rate. The bacteriological examination on the control day indicated that the bacteria isolated were different from those isolated at the initial examination; this was the situation for 14 cases. A shorter time period between treatment and control examination would possibly have affeced this tendency.

\section{REFERENCES}

Bakken, G.: Subclinical mastitis in Norwegian dairy cows. Prevalence rates and epidemiological assessments. Acta agric. scand. 1981, $31,273-286$.

Bakken, G. \& R. Gudding: The interdependence between clinical and subclinical mastitis. Acta agric. scand. 1982, 32, 17-22.

Brown, M. B.: Screening effects in multidimensional contingency tables. Appl. Stat. 1976, 25, 37-46.

Dixon, W. J. (ed) : BMDP Statistical Software 1981. University of California Press, Berkeley 1981, 727 pp.

Feinberg, S. E.: The analysis of Cross-classified Categorical Data. 2nd ed. MIT Press, Cambridge, MA 1980, $198 \mathrm{pp.}$

Kapur, M. P. \& R. P. Singh: Treatment of clinical mastitis: a comparison of four different formulations. Indian vet. J., 1978, 55, $320-325$. 
Kingwill, R.: Practical mastitis control. In: Regional Seminar on Bovine Mastitis. School of Veterinary Medicine, University of California, Davis 1978, p. 53-56.

Klastrup, O. \& P. Schmidt Madsen: Nordiske rekommendationer vedrørende mastitisunders $\varnothing$ gelser af kirtelprøver. (Scandinavian recommendations concerning investigation of quarter samples for mastitis). Nord. Vet.-Med. 1974, 26, 197-204.

Mercer, H. D., J. N. Geleta, R. A. Baldwin \& W. Shimoda: Viewpoint and current concepts regarding accepted and tried products for control of bovine mastitis. J. Amer. vet. med. Ass. 1976, 169, 1104-1114.

Newbould, F. H. S.: The use of induced mammary infections for evaluating dry cow treatment products II. Trial of a proposed method to compare three levels of Novobiocin. Canad. J. comp. Med. 1979, 43, 430-433.

Plommet, M. \& C. Le Louedec: The role of antibiotic therapy during lactation in the control of clinical and subclinical mastitis. In: F. H. Dodds, T. K. Griffen and R. G. Kingwill (eds) : Proceedings of Seminar on Mastitis Control, April 1975. IDF, Bruxelles 1975, p. 265-281.

Tolle, A.: Mastitis - the disease in relation to control methods. In: F. H. Dodds, T. K. Griffen and R. G. Kingwill (eds) : Proceedings of Seminar on Mastitis Control, April 1975, IDF, Bruxelles 1975, p. 3-15.

Ziv, G.: Practical pharmacokinetic aspects of mastitis therapy. In: Proceedings of Bovine Mastitis Regional Seminar, April 1978. School of Veterinary Medicine, University of California, Davis 1978, p. $1-52$.

Ziv, G.: Drug selection and use in mastitis: Systemic vs local therapy. J. Amer. vet. med. Ass. 1980, 176, 1109-1115.

\section{SAMMENDRAG}

En sammenligning av to doseringsnivå av antibiotika til intramammær behandling av klinisk mastitt hos ku.

Et klinisk fors $\varnothing \mathrm{k}$ ble utf $\varnothing r t$ i Nordre Valdres, Norge, for å undersøke effekten av en lav kontra en h $\varnothing y$ dosering av intramammær antibiotikabehandling av klinisk mastitt. Av interesse var også å identifisere signifikante riskfaktorer, samt å kunne estimere sannsynligheten for "ikke helbredelse" under gitte definerte nivå av riskfaktorer. Enkeltspenepr $\varnothing$ ver fra $166 \mathrm{kyr}$ med klinisk mastitt ble unders $\varnothing \mathrm{kt}$ f $\varnothing \mathrm{r}$ og etter behandling, med tre ukers mellomrom. De to doseringsnivåne var ikke signifikant forskjellige med henblikk på helbredelsesprosenten. Beregningene viste videre at dyrets almentilstand, laktasjonsår, bakteriologiske funn, samt lokalisasjon av affisert kjertel virket inn på behandlingsresultatet.

(Received January 31, 1984).

Reprints may be requested from: Jostein Bjorland, the National Veterinary Institute, P. O. Box 8156 Dep., Oslo 1, Norway. 